\title{
Morphology of Proximal Cortical Epiphysis Bone of Ovariectomized Rattus Norvegicus
}

\author{
Ovariektomize Rattus Norvegicus'un Proksimal Kortikal Epifiz Kemiğinin Morfolojisi
}

(D) Neng Nenden Mulyaningsih, (D) Ariadne Lakshmidevi Juwono, (D) Djarwani Soeharso Soejoko, (D) Dewi Apri Astuti*

Universitas Indonesia Faculty of Mathematics and Natural Sciences (FMIPA), Department of Physics, Depok 16424, Indonesia

*Bogor Agricultural University Faculty of Animal Sciences, Department of Nutrition and Feed Technology, Bogor 16680, Indonesia

\section{Abstract}

Objective: Osteoporosis could affect anyone, both men and women and young and old. This study aimed to analyse the morphology of ovariectomy $(\mathrm{OVX})$ to the proximal cortical epiphysis bone using scanning electron microscope (SEM) and transmission electron microscope (TEM) on ovariectomised rat models.

Materials and Methods: The analysed bones were the cortical femur bones taken from ovariectomised female Rattus norvegicus. Characterisation was performed from the third week of OVX and continued at the fifth, seventh and ninth weeks. The analysis was focused on two levels of structure, including the microstructure level with a magnification of $100 \mu \mathrm{m}$, which was obtained from SEM images to analyse the shape and intensity of the bone cavity, and the nanostructure level with a magnification of $50 \mathrm{~nm}$, which was obtained from TEM images to analyse the bone apatite crystals.

Results: At the microstructure level, the cavity that appeared in 9-week-old ovariectomised rats was found to increase by $68.9 \%$ compared to that of the control group (non-OVX). In addition, at the nanostructure level, the plate, tablet and overlapping apatite crystals were present in both the non-OVX and OVX rats. However, a tendency of the tablet size of apatite crystals to decline was observed in the ovariectomised rats group.

Conclusion: White female Rattus norvegicus showed osteoporosis conditions based on the morphology and percentage of cavities at 9 weeks of OVX. In addition, OVX lowered the size of apatite crystals.

Keywords: Osteoporosis, ovariectomy, morphology of bone, bone cavity, bone apatite crystals

\section{$\ddot{O z}$}

Amaç: Osteoporoz tüm yaşlardaki kadın ve erkek bireyleri etkileyebilir. Bu çalısmanın amacı ovariektomi (OVX) proksimal kortikal epifiz kemiğinin morfolojisini, ovariektomize edilmiş sıçan modellerinde taramalı elektron mikroskobu (SEM) ve transmisyon elektron mikroskobu (TEM) kullanarak analiz etmektir.

Gereç ve Yöntem: Analiz edilen kemikler ovariektomize Rattus norvegicus dişi sıçanlardan alınan kortikal femur kemikleriydi. OVX'in beşinci, yedinci ve dokuzuncu haftada devam etmesinden bu yana üçüncü haftadan itibaren karakterizasyon yapıldı. Analiz, TEM yapısından elde edilen kemik çukurunun ve nanoyapı seviyesinin şeklini ve yoğunluğunu analiz etmek için SEM görüntülerinden elde edilen 100 ㅆm büyütmeli mikroyapı seviyesi olan iki yapı seviyesine odaklanıyordu - TEM görüntülerinden elde edilen 50 nm'lik bir büyütme ile nanoyapı seviyesinin analiz edilmesi - kemik analizi apatit kristalleri.

Bulgular: Mikroyapı düzeyinde, OVX'ten bu yana 9 haftalık sıçanlarda ortaya çıkan boşluğun kontrol grubuna (OVX olmayan) kıyasla \%68,9 arttığı tespit edildi. Nanoyapı düzeyinde, plaka, tablet ve örtüşen apatit kristallerinin hem OVX olmayan hem de OVX sıçanlarında mevcut olduğu anlaşılmaktadır. Bununla birlikte, ovariektomize edilmiş sıçanlar grubunda, apatit kristallerinin tablet boyutunun düşme eğilimi vardı.

Sonuç: Rattus norvegicus beyaz sıçanlarının dişileri OVX'ten bu yana 9. haftada morfolojiye ve oyukların yüzdesine dayanan osteoporoz koşulları göstermiştir. OVX ayrıca apatit kristallerinin boyutunu da düşürdü.

Anahtar kelimeler: Osteoporoz, overiektomi, kemik morfolojisi, kemik boşluğu, kemik apatit kristalleri 


\section{Introduction}

The process of bone regeneration is influenced by many hormones, including the estrogen hormone $(1,2)$. Changes in hormone levels can affect of bone density (3). In women, the estrogen hormone is needed to maintain bone health (4). After menopause, the estrogen levels in the body decrease which also results in a dramatic decrease in bone density (5). In women who are still fertile there can be also a decrease in estrogen levels, one of the contributing factors is the ovary removal [ovariectomy $(O V X)](6)$. Therefore, the interference with estrogen-producing organs can be at risk for osteoporosis, because estrogen helps to absorb calcium into the bone, so that bone density decreases and this condition causes bones to become porous and prone to cracking (7-10).

Osteoporosis can occur to everyone, but some people are more at risk and experience this condition more quickly than others. Osteoporosis is generally only known after a fracture is founded in the bone, after a person has experienced a mild fall (11-13). Fractures usually occur in the spine (14), wrist (15) or groin (16). People with osteoporosis rarely know early that they suffer from osteoporosis, because there are no special characteristics. Usually the people are aware when the osteoporosis at an advanced stage.

Hierarchically, bones were divided into five levels, namely nanostructures (ranging from few nanometers to several hundred nanometers), sub-microstructural level (spanning 1 to a few microns), microstructural level (tenths to hundreds microns), mesostructural level (several hundred microns to several millimeters), and macrostructural level (several millimeters to several centimeters, depending on the species) $(17,18)$. Bone quality can be investigated visually based on its shape and structure using scanning electron microscope (SEM) and transmission electron microscope (TEM) observations. SEM is used to analyze the surface of the bone at the microstructure level, while TEM is used to analyze the crystal structure in the bone at the nanostructure level $(19,20)$. There has been no advanced study about ovariectomized rats in certain times in their micro and nano structure levels. In this study, SEM and TEM were employed to analyze the morphology of the femur from ovariectomized rats.

Most previous studies have reported a result of characterization with SEM or TEM for normal bone and osteoporosis $(21,22)$. In a microstructure level, osteoporosis has more cavities than normal bones. However, there were no studies that show the number of cavities that were owned by each normal bone and osteoporosis bone. Likewise on the nanostructure level, osteoporosis rats have a smaller apatite crystal size compared to normal rats, but no one has mentioned how fast the crystal size decreases. Futhermore, we aimed to determine the cavity intensity and crystal size of apatite from rats that were ovariectomized every two weeks until the ninth week since OVX.

\section{Materials and Methods}

\section{Sample Preparation}

Proximal cortical epiphysis bone material was extracted from a femur of female Sprague-Dawley rats (Rattus norvegicus species) at 12 weeks of age and (235.0 \pm 5.2$) \mathrm{g}$ of weight. Samples were collected at National Agency of Drug and Food Control. The rats were fed with a control diet (AIN 93G), water, and fed ad libitum. The animals were divided into two groups: unoperated basal control rats (non-OVX rats) and ovariectomized rats (OVX rats). The non-OVX rats were sacrificed at 12 weeks of age, and their femur bones were dissected, which will be hereafter designated as control femur (FC). The rats ovariectomized at 12 weeks of age were sacrificed at 3 (FO3), 5 (FO5), 7 (FO7) and 9 (FO9) weeks after OVX and the femur bodies were harvested.

Animal maintenance and OVX were carried out at the Laboratory of Experimental Surgery, Division of Surgery and Radiology, Department of Animal Husbandry, Faculty of Veterinary Medicine, Bogor Agricultural University. Bone sample preparation and morphological characterization were carried out at the SEM and TEM Laboratory University of Indonesia.

\section{Characterization}

Bone microstructure and nanostructure can be identified based on the analysis of images from SEM and TEM respectively. One indicator of osteoporosis is enlargement of the cavities in the bone which results in bone loss. The femur bone was the proximal cortical epiphyseal part. This part is one of the parts that are often found in fractures of bones that have osteoporosis. SEM images were processed using the ImageJ application and the data were presented in the form of histograms and percentage of cavity intensity. TEM characterization was carried out to analyze the crystal structure of the bone and measured apatite crystal size.

\section{Statistical Analysis}

Numerical data were presented as the mean and standard deviation. The data were presented as the number and percentage. An unpaired two sample t-test was used to analyze the statistical significance of crystal size in normal and ovariectomized rats. Statistical significance was set at $p<0.05$.

\section{Results}

\section{Microstructure}

The SEM image of the control group (Figure 1a) shows that the surface was still flat and compact. In the group of rats which were ovariectomized starting from FO3 (Figure 1b), it is clear that the appearance of fine fibers and more holes, almost evenly on all the bone. The fibers in the FO5 (Figure 1c) group were rougher and the holes were deeper. In the FO7 (Figure 1d) and FO9 (Figure 1e) groups they are appeared to be mixed of flat and fibrous texture and visible holes unite, so that the hole becomes wide and the surface becomes coarser. The rough and enlarged 
surface of the hole indicate the presence of minerals lost in the bone. One of the minerals lost in the bone that is calcium (23).

\section{Percentage of Cavity Intensity}

In addition to visual observations of SEM images, pixel analysis of SEM images were also carried out through histogram data with the ImageJ application as shown in Figure 1f-j. Based on that figure, the group of ovariectomized rats had histograms which increasingly shifted more black areas. Areas that were black or dark relate to cavities in the bone. In the control group, the histogram was more dominant in the white area, which means fewer cavities. The longer the time since OVX, the lower the average intensity. The average value of intensity was proportional to the white area.

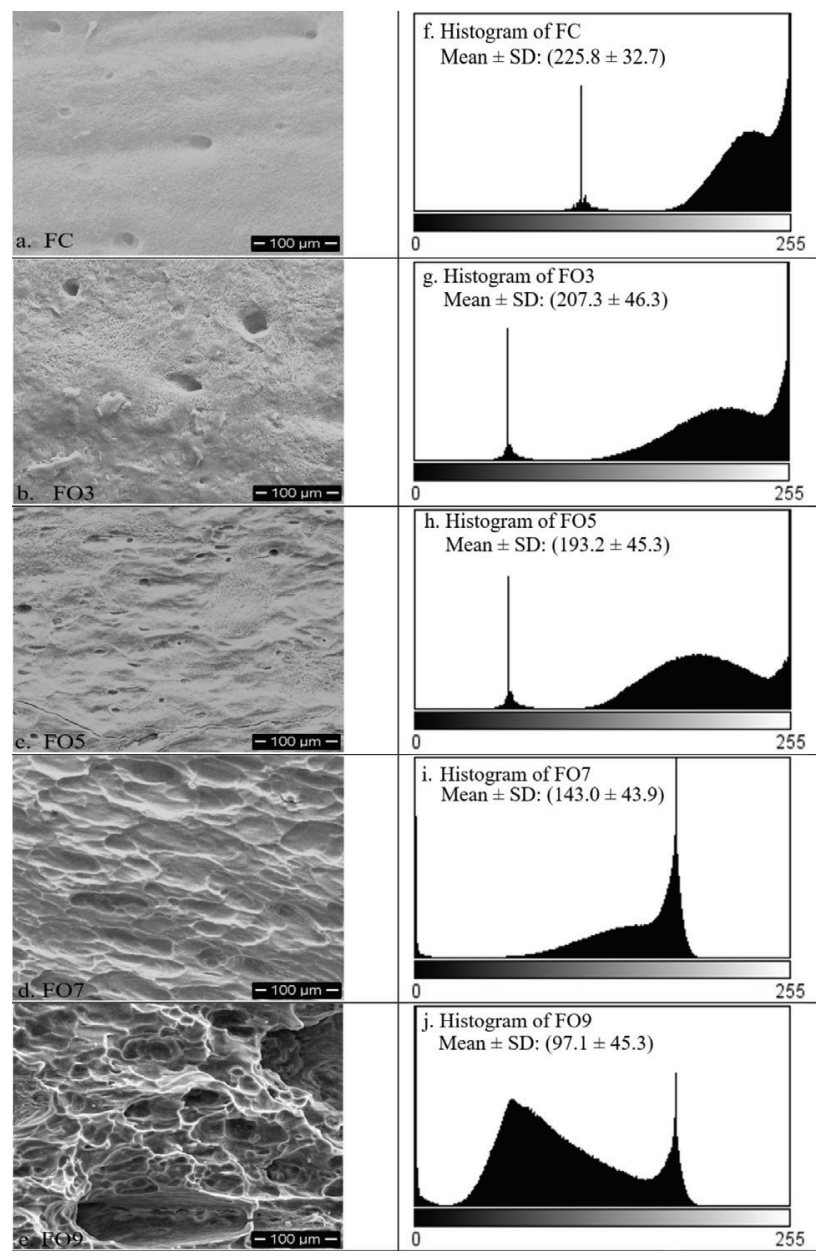

Figure 1. Electron microscopy and histogram of femur (1,000 times): (a) non-ovariectomy (OVX) rats; (b) rats were sacrificed at 3 weeks after OVX; (c) rats were sacrificed at 5 weeks after OVX; (d) rats were sacrificed at 7 weeks after OVX; (e) rats were sacrificed at 9 weeks after OVX; (f) histogram for non-OVX rats; (g) histogram for rats were sacrificed at 3 weeks after OVX; (h) histogram for rats were sacrificed at 5 weeks after OVX; (h) histogram for rats were sacrificed at 7 weeks after OVX; (j) histogram for rats were sacrificed at 9 weeks after OVX.

FC: Non-ovariectomy rats, FO3-FO9: Rats were sacrificed at 3-9 weeks after ovariectomy, SD: Standard deviation
The average cavity intensity from the histogram data of the SEM image of the femur bone is shown in Table 1. From that table, the average intensity for the control group/FC (225.8 \pm 32.7$)$ pixel and for the FO9 group $(97.1 \pm 45.3)$ pixel, with the percentage of cavity intensity respectively at $14.5 \%$ and $46.6 \%$. Based on the percentage of cavity intensity, nine weeks after OVX, the cavity in the femur bone increased by $68.9 \%$. The cavity that appears in FO9 group rats can lead bones to become brittle and easily broken if the bones are exposed to a hard object (24).

\section{Nanostructure}

The results of TEM characterization are shown in Figure 2. Based on the TEM images, the basic shapes in each image were visible, which were crystal structures that resemble plate, tablet (elongated oval) and overlapping apatite. The three forms are shown in different signs in the figure. The arrow signs are for plate-like parts, the dashed arrow signs are for apatites which form tablets, and the circle-marked signs are for the overlapping parts.

\section{Apatite Crystal Size}

Plate apatite crystals were scattered randomly, irregular shapes, and bumpy edges. These forms are similar to the research that was previously (25). Apatite crystals that resemble tablet form, in the control group have a longer size (Figure 2a), and for groups of ovariectomized rats there was a decrease in size both length and width (Figure $2 \mathrm{~b}-\mathrm{e}$ ). The overlapping parts of apatite crystals were difficult to analyze, so the size of apatite crystals only measured in the tablet shaped part. The results were shown in Table 2.

The values listed in Table 2 show the average length and width of the apatite crystal with the standard deviation. Based on Table 2, the group of ovariectomized rats has a range of apatite crystal lengths ranging from $(43.0 \pm 7.4) \mathrm{nm}$ to $(56.2 \pm 4.0) \mathrm{nm}$. This range of value was shorter than the length value of the crystal size of the control group (57.6 \pm 2.3$) \mathrm{nm}$. Independent t-test of control (non-OVX) and OVX groups exhibited significant differences in apatite crystal length $(p<0.05)$. In a previous study, obtained a crystal length in the form of tablets from normal rats are $(50.7 \pm 9.1) \mathrm{nm}(26)$ and $(63.9 \pm 23.5) \mathrm{nm}(27)$. Some of the factors that lead to differences in the results obtained include

Table 1. Percentage of cavity intensity from histogram data of scanning electron microscope image (mean \pm standard deviation)

\begin{tabular}{|l|l|l|}
\hline Group & $\begin{array}{l}\text { Total cavity } \\
\text { intensity (pixel) }\end{array}$ & $\begin{array}{l}\text { Cavity } \\
\text { intensity (\%) }\end{array}$ \\
\hline FC & $225.8 \pm 32.7$ & 14.5 \\
\hline FO3 & $207.3 \pm 46.3$ & 22.3 \\
\hline FO5 & $193.2 \pm 45.3$ & 23.5 \\
\hline FO7 & $143.0 \pm 43.9$ & 30.7 \\
\hline FO9 & $97.1 \pm 45.3$ & 46.6 \\
\hline $\begin{array}{l}\text { FC: Non-ovariectomy rats, FO3-FO9: Rats were sacrificed at 3-9 weeks after } \\
\text { ovariectomy }\end{array}$ \\
\hline
\end{tabular}




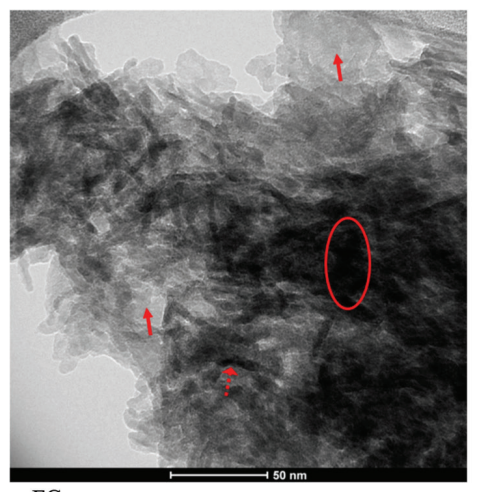

a.FC

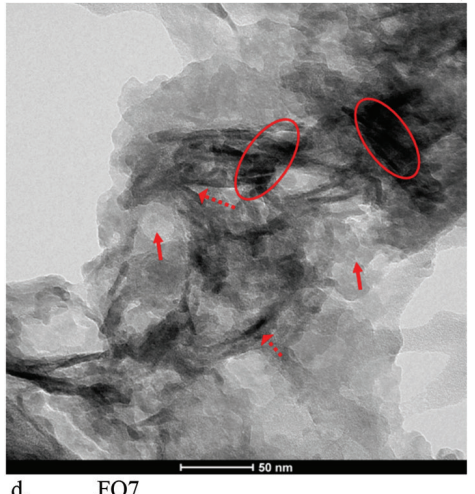

FO7
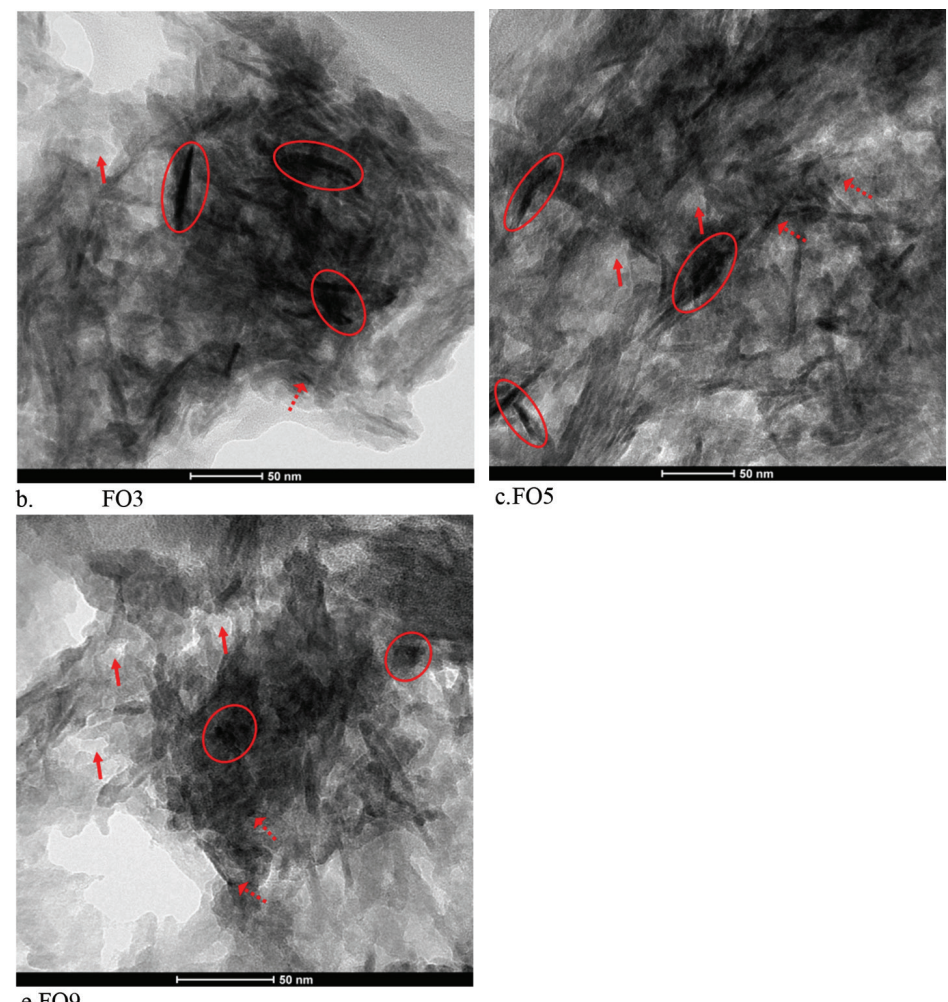

c.FO5

Figure 2. TEM image of rat femur (50 nm): (a) non- ovariectomy $(O V X)$ rats; (b) rats were sacrificed at 3 weeks after OVX; (c) rats were sacrificed at 5 weeks after OVX; (d) rats were sacrificed at 7 weeks after OVX; (e) rats were sacrificed at 9 weeks after OVX.

FC: Non-ovariectomy rats, FO3-FO9: Rats were sacrificed at 3-9 weeks after ovariectomy, SD: Standard deviation

\begin{tabular}{|c|c|c|}
\hline \multirow{2}{*}{ Group } & \multicolumn{2}{|c|}{ Crystal size $(\mathrm{nm})$} \\
\hline & Length & Width \\
\hline FC & $57.6 \pm 2.3$ & $7.6 \pm 1.2$ \\
\hline FO3 & $56.2 \pm 4.0$ & $7.5 \pm 1.2$ \\
\hline FO5 & $55.7 \pm 3.6$ & $7.5 \pm 1.3$ \\
\hline FO7 & $48.2 \pm 5.3$ & $7.2 \pm 1.2$ \\
\hline FO9 & $43.0 \pm 7.4$ & $6.7 \pm 1.2$ \\
\hline \multicolumn{3}{|c|}{$\begin{array}{l}\text { FC: Non-ovariectomy rats, F03-F09: Rats were sacrificed at 3-9 weeks after } \\
\text { ovariectomy }\end{array}$} \\
\hline
\end{tabular}

different technique and sample preparation methods, sample grinding and sifting techniques, and light or dark quality in the image.

When viewed from the size of the width, the average was almost the same. The difference was not significant between the control group and the OVX group of rats at $p<0.05$. In a previous study, also obtained results that were not significantly different for width measurements, both in normal bone apatite crystals and osteoporosis bone (28-31). The low size of the crystal, both its length and width, shows that in ovariectomized rats a decrease in bone density. Low bone density is more fragile. This condition is a feature of osteoporotic bone (32).

\section{Discussion}

SEM examination showed that OVX causes increased bone cavity and based on TEM observations showed that apatite crystal size decreased in rats which were ovariectomized. Healthy femur bone (FC) had cavity intensity of $14.5 \%$. Cavities in healthy bones were needed to produce red blood cells. The research conducted previously showed that healthy bone cavities were $12 \%$ and $18 \%(33,34)$. This value confirms that the femur bone used as a control is a healthy bone standard. When the cavity widens and gets bigger, the bones will break easily $(35,36)$. From the SEM images, it can be seen that starting 3 weeks after OVX (cavity intensity 22.3\%), the cavities appear deeper than the SEM image of the control femur. This result supports of a research conducted previously (37). Likewise, at the fifth week $(23.5 \%)$, the seventh $(30.7 \%)$ to the ninth $(46.6 \%)$, the cavities widen. Estrogen deficiency caused an increase in cortical vascular porosity and an increase in cortical vascular ductal diameter in the proximal tibia of rats (38).

Similar with most previous studies, researchers observed a morphology of bone with SEM and TEM (39). Maximum cavity in the normal bone was $24-28 \%$ (40), so the results of the study showed that the intensity of cavity was $46.6 \%$ in the ninth week after the OVX has crossed the normal bone cavity threshold. The TEM characterization results supported SEM results. Apatite crystals in ovariectomized rats were smaller in size compared to groups of rats which were non-OVX. For 9 weeks since OVX, 
the length and width of apatite crystals decreased by $25.3 \%$ and $11.8 \%$ respectively. A decrease in crystal size indicates that there is a decrease in ions in the bone. This support with a previous study which reported that a decrease in apatite crystal size is $68.2 \%$ (41). However, these results contradict from the other research that osteoporosis rats had a larger crystal size. A previous study obtained that porosity was proportional to the crystal size (42). The difference of crystal size due to the diversity of individuals used and the method of research conducted.

\section{Study Limitations}

The present study has several strengths and limitations. A limitation is the qualitative data in the form of images that are subjective. There are also important limitations in taking pictures in the laboratory and adjusting the brightness level of the image. SEM and TEM images provide only information on bone structure and not on bone chemistry or its properties. Furthermore, they only give two-dimensional information on a partial structure of three-dimensional data are inferred. Further research is needed to evaluate the level of overlapping and distinct chemical data distribution pattern of apatite crystal.

\section{Conclusion}

In summary, SEM and TEM analyses of proximal cortical epiphysis bone of Rattus norvegicus showed that 9 weeks since OVX, rats were already in osteoporosis. This condition was characterized by the percentage of cavity intensity of $68.9 \%$ which exceeds the maximum limit of cavity intensity in normal bone. This condition was supported by a decrease in the size of the apatite crystal length by $25.4 \%$ and its width reduced by $11.8 \%$.

\section{Ethics}

Ethics Committee Approval: This experiment was approved by the Ethics Committee of the Faculty of Medicine, University of Indonesia (protocol number 17-05-0421).

Informed Consent: This is an animal experiment.

Peer-review: Externally peer-reviewed.

\section{Authorship Contributions}

Surgical and Medical Practices: N.N.M., D.A.A., Concept: N.N.M., D.S.S., Design: N.N.M., D.A.A., Data Collection or Processing: N.N.M., Analysis or Interpretation: N.N.M., A.L.J., Literature Search: N.N.M., Writing: N.N.M., A.L.J.

Conflict of Interest: No conflict of interest was declared by the authors.

Financial Disclosure: The study was supported by a grant from the Universitas Indonesia for doctoral program No. 1331/UN2. R3.1/HKP.05.00/2018

\section{References}

1. Ling-Ling $E, X u W$, Feng $L$, Liu $Y$, Cai $D$, We $N$, et al. Estrogen enhances the bone regeneration potential of periodontal ligament stem cells derived from osteoporotic rats and seeded on nano-hydroxyapatite/collagen/poly(L-lactide). Int J Mol Med 2016;37:1475-86.
2. Sharma D, Larriera Al, Palacio-Mancheno PE, Gatti V, Fritton JC, Bromage TG, et al. The effects of estrogen deficiency on cortical bone microporosity and mineralization. Bone 2018;110:1-10.

3. Jiang L, Zhang W, Wei L, Zhou Q, Yang G, Qian N, et al. Early effects of parathyroid hormone on vascularized bone regeneration and implant osseointegration in aged rats. Biomaterials 2018;179:1528.

4. Almeida $M$, Laurent MR, Dubois $V$, Claessens F, O'Brien CA, Bouillon $\mathrm{R}$, et al. Estrogens and androgens in skeletal physiology and pathophysiology. Physiol Rev 2017;97:135-87.

5. Leticia SS, Rochette NF, Pedrosa DF, Magnago RPL, Filho TBF, Vieira FLH, et al. Role of APOE gene in bone mineral density and incidence of bone fractures in brazilian postmenopausal women. J Clin Densitom 2018;22:227-35.

6. Fang J, Yang L, Zhang R, Zhu X, Wang P. Are there differences between Sprague-Dawley and Wistar rats in long-term effects of ovariectomy as a model for postmenopausal osteoporosis?. Int J Clin Exp Pathol 2015;8:1491-502.

7. Laurent MR. Role of estrogens and androgens in osteoporosis. Ref Module in Biomed Sci 2019;4:233-45.

8. Rossini M, Lello S, Sblendorio I, Viapiana O, Fracassi E, Adami S, et al. Profile of bazedoxifene/conjugated estrogens for the treatment of estrogen deficiency symptoms and osteoporosis in women at risk of fracture. Drug Des Devel Ther 2013;22:601-10.

9. Dasarathy JMD, Labrador H. Bone Health in Women. Prim Care 2018;45:643-57.

10. Balla B, Sarvari M, Kosa JP, Kocsis-Deák B, Tobiás B, Árvai K, et al. Long-term selective estrogen receptor-beta agonist treatment modulates gene expression in bone and bone marrow of ovariectomized rats. The J of Ster Biochem and Mol Bio 2019;188:185-94.

11. Marcucci G, Brandi ML. Rare causes of osteoporosis. Clin Cases Miner Bone Metab 2015;12:151-6.

12. Trajanoska K, Rivadeneira F. The genetic architecture of osteoporosis and fracture risk. Bone 2019;126:2-10.

13. Edwards BJ. Osteoporosis Risk Calculators. J Clin Densitom 2017;20:379-88.

14. Zammel N, Amri N, Chaabane R, Rebai T, Badraoui R. Proficiencies of Zingiber officinale against spine curve and vertebral damage induced by corticosteroid therapy associated with gonadal hormone deficiency in a rat model of osteoporosis. Biomed Pharmaco 2018;103:1429-35.

15. Wu JC, Strickland $C D$, Chambers JS. Wrist Fractures and Osteoporosis. Orthop Clin North Am 2019;50:211-21.

16. Rastogi A, Cross S, Gademsetty C, Ramachandran M, Ahmad M, Jalan R. Imaging of the hip and groin. Orthop Trauma 2014;28:25675.

17. Hamed E, Lee $Y$, Jasiuk I. Multiscale modeling of elastic properties of cortical bone. Acta Mech 2010;213:131-54.

18. Hamed E, Jasiuk I, Yoo A, Lee YH, Liszka T. Multi-scale modelling of elastic moduli of trabecular bone. J R Soc Interface 2012;9:165473.

19. Rubin MA, Jasiuk I. The TEM characterization of the lamellar structure of osteoporotic human trabecular bone. Micron 2005;36:653-64.

20. Mitić Ž, Stolić A, Stojanović S, Najman S, Ignjatović N, Nikolić G, et al. Instrumental methods and techniques for structural and physicochemical characterization of biomaterials and bone tissue: A review. Mater Sci Eng C 2017;79:930-49.

21. Rubin MA, Jasiuk I, Taylor J, Rubin J, Ganey T, Apkarian RP. TEM analysis of the nanostructure of normal and osteoporotic human trabecular bone. Bone 2003;33:270-82.

22. Kim JK, Kwon YE, Lee SG, Jeong JM, Kim JG, Kim YJ. Comparative SEM and TEM analyses of apatite phases prepared by a multisample loading device. Materi Characteriz 2018;135:1-7.

23. Mulyaningsih NN, Juwono AJ, Soejoko DS, Astuti DA. Analysis of nano $\mathrm{Ca}_{3}\left(\mathrm{PO}_{4}\right)_{2}$ on bone's calcium deficiency at peak age. In: IOP Conf. Series: Earth and Environmental Science, The $4^{\text {th }}$ International Seminar on Sciences. Baranangsiang, Bogor, Indonesia: Bogor Agricultural University 2018;187:1-7. 
24. Osterhoff G, Morgan EF, Shefelbine SJ, Karim L, McNamara $L M$, Augat P. Bone mechanical properties and changes with osteoporosis. Injury 2016;47:11-20.

25. Eppell SJ, Tong W, Katz JL, Kuhn L, Glimcher MJ. Shape and size of isolated bone mineralites measured using atomic force microscopy. J Orthop Res 2001;19:1027-34.

26. Rubin MA, Rubin J, Jasiuk I. SEM and TEM study of the hierarchical structure of $\mathrm{C} 57 \mathrm{BL} / 6 \mathrm{~J}$ and $\mathrm{C} 3 \mathrm{H} / \mathrm{HeJ}$ mice trabecular bone. Bone 2004;35:11-20.

27. Dumont M, Kostka A, Sander PM, Borbely A, Kaysser-Pyzalla A Size and size distribution of apatite crystals in sauropod fossil bones. Palaeo 2011;310:108-16.

28. Turunen MJ, Kaspersen JD, Olsson U, Guizar-Sicairos M, Bech $M$ Schaff $F_{\text {, et }}$ al. Bone mineral crystal size and organization vary across mature rat bone cortex. J Struct Biol 2016;195:337-44

29. Bohic S, Rey C, Legrand A, Sfihi H, Rohanizadeh R, Martel C, et al. Characterization of the trabecular rat bone mineral: effect of ovariectomy and biphosphonate treatment. Bone 2000;26:341-8.

30. Fratzl F, Vogl G, Eschberger J, Koller K, Groschner M, Plenk H, et al. Mineral crystals in calcified tissues: A comparative study by SAXS J Bone Miner Res 2009;7:329-34.

31. ShunsukeY, Mary CW, Suhaib B, Timothy CC, Cecilia MG. Loss of PiT-2 results in abnormal bone development and decreased bone mineral density and length in mice. Biochem. Biophys Res Commun 2018;495:553-9.

32. Ferrari S, Reginster JY, Brandi ML, Kanis JA, Devogelaer JP, Kaufman $\mathrm{JM}$, et al. Unmet needs and current and future approaches for osteoporotic patients at high risk of hip fracture. Arch Osteoporos 2016;11:37

33. Keaveny TM, Hayes WC. A 20-year perspective on the mechanical properties of trabecular bone. J Biomech Eng 1993;115:534-42.
34. Zebaze RM, Ghasem-Zadeh A, Bohte A, Iuliano-Burns S, Mirams $\mathrm{M}$, Price Rl, et al. Intracortical remodelling and porosity in the distal radius and post-mortem femurs of women: a cross-sectional study. Lancet 2010;375:1729-36.

35. Gong $H$, Zhang $M$, Yeung HY, Qin L. Regional variations in microstructural properties of vertebral trabeculae with aging. J Bone Miner Metab 2005;23:174-80.

36. Rajapakse CS, Bashoor-Zadeh M, Li C, Sun W, Wright AC, Wehrli FW. Volumetric cortical bone porosity assessment with MR imaging: validation and clinical feasibility. Radiology 2015;276:526-35.

37. Mbarki M, Sharrock P, Fiallo M, ElFeki H. Hydroxyapatite bioceramic with large porosity. Materials Sci and Engineering C 2017;76:98590.

38. Sharma D, Ciani C, Marin PA, Levy JD, Doty SB, Fritton SP. Alterations in the osteocyte lacunar-canalicular microenvironment due to estrogen deficiency. Bone 2012;51:488-97.

39. Bagambisa FB, Joos U, Schilli W. A scanning electron microscope study of the ultrastructural organization of bone mineral. Cell Mater 1993:3:93-102.

40. Mansilla J, Moreno-Castilla C, Bosch P, Alemán I, Pijoan C, Botella M. On porosity of archeological bones II. textural characterization of mesoamerican human bones. Palaeogeogr Palaeoclimatol Palaeoecol 2014;414:493-9.

41. Rollo JMDA, Boffa RS, Cesar R, Schwab DC, Leivas TP. Assessment of trabecular bones microarchitectures and crystal structure of hydroxyapatite in bone osteoporosis with application of the rietveld method. Procedia Eng 2015;110:8-14.

42. Noor Z, Hidayat M, Taufik A, Sumitro S, Rahim AH. Assessment of microarchitecture and crystal structure of hydroxyapatite in osteoporosis. Univ Med 2011;30:29-35. 